\title{
Developmental Exposure to Polybrominated Diphenyl Ethers and Neurodevelopment
}

\author{
Julie B. Herbstman • Jennifer K. Mall
}

Published online: 24 April 2014

(C) Springer International Publishing AG 2014

\begin{abstract}
Exposure to polybrominated diphenyl ethers (PBDEs) during sensitive developmental windows can interfere with cognitive function and behavior, which are critical components of neurodevelopment. The association between developmental exposure to PBDEs and neurodevelopment has been extensively studied using animal models. In this review, we focus on the accumulating evidence in humans. Despite methodologic, geographic, and temporal differences between studies, the majority of the epidemiologic evidence supports that early-life exposure to PBDEs measured during pregnancy and/or during childhood is detrimental to child neurodevelopment in domains related to child behavior, cognition, and motor skills. While the precise mechanism of action of PBDEs on neurodevelopment is unknown, PBDEinduced neurotoxicity via thyroid hormone disruption and direct action of PBDEs on the developing brain have been proposed and tested. Additional studies are suggested to better understand how early-life and/or childhood PBDE exposures, including exposure to specific PBDE congeners, impact neurodevelopmental indices.
\end{abstract}

Keywords Polybrominated diphenyl ethers .

Neurodevelopment $\cdot$ Epidemiology $\cdot$ Perinatal .

Developmental exposure

\footnotetext{
J. B. Herbstman $(\square)$

Columbia Center for Children's Environmental Health, Department of Environmental Health Sciences,

Columbia Mailman School of Public Health, 722 W168th Street,

Room 1217, New York, NY 10032, USA

e-mail: jh2678@columbia.edu

J. K. Mall

School of Medicine, Faculty of Health Sciences,

Trinity College Dublin, College Green, Dublin 2, Ireland

e-mail: mallj@tcd.ie
}

\section{Introduction}

Neurodevelopmental processes begin soon after conception and, in humans, continue through the first years of life, and through adolescence into early adulthood [1]. Neurodevelopment can be disrupted leading to neurodevelopmental disorders, which are a group of conditions associated with impaired learning, language, or behavior. One or more of these conditions affect $17 \%$ of children under 18 years of age in the US [2]. In 2009, $19 \%$ of US children between 4 and 17 years of age had a parental report of difficulties with a broad range of symptoms including control of emotions, concentration, behavior, or interacting with other people [3]. According to the National Health Interview Survey in 2010, 5 million US children aged $3-17$ years ( $8 \%$ of this age group) had ever received a diagnosis of attention-deficit/hyperactivity disorder (ADHD) [4]. ADHD is characterized by impulsive behavior and inattention and often affects cognitive abilities involved in executive function [5]. In the US, ADHD diagnoses have increased over time, and are now considered the most commonly diagnosed neurobehavioral disorders of childhood [6]. A diagnosis of ADHD often co-occurs with learning disabilities and other behavioral disorders such that $28 \%$ of children diagnosed with either learning disabilities or ADHD reported having been diagnosed with both conditions [7]. It has also been estimated that approximately one third of childhood ADHD cases persist into adulthood [8]. Studies examining the economic impacts including costs related to healthcare, special education, parental work loss, disciplinary actions, and the juvenile justice system estimate that ADHD is associated with US $\$ 12,005$ and US $\$ 17,458$ per affected individual and US $\$ 42.5$ billion annually (based on a conservative $5 \%$ population prevalence in the US) [9].

Exposure to environmental chemicals occurring during sensitive development windows can interfere with cognitive function and behavior, both of which are critical components 
of neurodevelopment. Polybrominated diphenyl ethers (PBDEs) are a group of 209 organohalogenated compounds ("congeners", numbered according to their degree of bromination and position of bromine atoms on the diphenyl ether backbone) that are produced as three commercial mixtures penta-, octa-, and deca-brominated diphenyl ethers (BDEs) (Fig. 1). The penta-BDE mixture is $24-38 \% \mathrm{BDE}$ with four bromines (e.g., BDE-47), 50-60 \% BDE with five bromines (e.g., BDE-99, 100), and 4-8 \% BDE with six bromines (e.g., BDE-153, 154). Octa-BDE mixture is 10-12\% BDE with six bromines, $44 \%$ BDE with seven bromines, 31-35\% with eight bromines, $10-11 \%$ BDE with nine bromines, and $<1 \%$ fully brominated (BDE-209). The Deca-BDE mixture contains a small amount of BDE with eight bromines, $<3 \%$ of BDE with nine bromines, and $>97 \%$ BDE-209 [10॰].

PBDEs have been among the most highly used chemical compounds for reducing flammability because of their low cost and availability [11, 12]. They have been added to a wide variety of consumer products including furniture, textiles, electronics, and construction materials to reduce product flammability and meet regulatory requirements. Because PBDEs are additive compounds and are not chemically bound to consumer products, they have the propensity to migrate into the external environment [13]. They are persistent, organic chemicals, are lipophilic, and can bioaccumulate in fatty tissues. Their estimated half-life is 1.6 years in sediment [14] and 1.8-6.5 years in humans [15]. Therefore, PBDEs have become ubiquitous contaminants, detectable in humans, in animals, and in all aspects of the environment [16•, 17].

PBDE exposure varies geographically, with age, and over time [16•]. While concentrations measured in food from Europe, Asia, and the US are similar, household dust concentrations in the US greatly exceed measurements from Europe and most Asian countries [18-21]. In humans, PBDE body burdens are approximately an order of magnitude higher in US individuals compared with Europeans and Asians [16•], implicating dust as the principal exposure pathway [22]. In cross-sectional studies, children have, on average, 2- to10-fold higher PBDE concentrations than adults [23-25]. This is concerning because neonates and children have rapidly developing nervous systems and reduced abilities to metabolize and excrete environmental contaminants they encounter [26].

In response to their ubiquity and concern over associated health effects, Europe banned penta- and octa-BDEs outright in 2004 and prohibited the use of deca-BDEs in electronics and electrical equipment in 2006 [27]. In 2004, there was a voluntary phase-out of penta- and octa-BDEs in the US. This voluntary phase-out followed a series of US states, including

Fig. 1 PBDE commercial mixtures. (Adapted from: Birnbaum LS, Staskal DF (2004) Brominated flame retardants: cause for concern? Environmental health perspectives 112: 9-17) [10 ]. $P B D E$ polybrominated diphenyl ether, $B D E$ brominated diphenyl ether

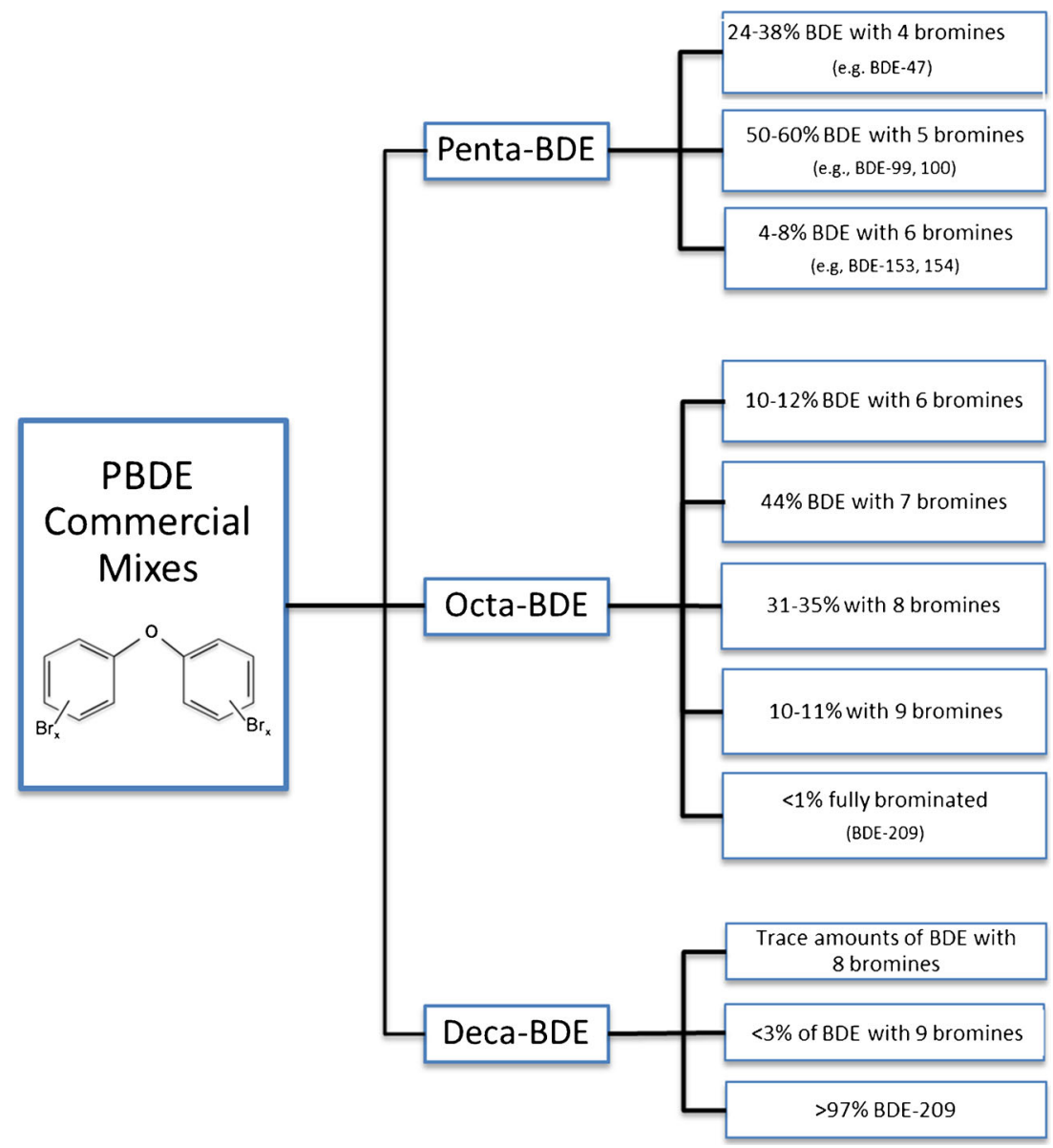


California, banning penta- and octa-BDEs. Interestingly, California's state-level flammability standard (TB-117) was one of the original driving forces behind the widespread use of PBDEs in upholstered furniture. Shortly after the removal of penta- and octa-BDEa, deca-BDE was also phased out of production over the course of 3 years beginning in 2009 [28•]. In Asia, China is the major producer of PBDEs. However, the production has decreased in recent years because of concerns about dioxin production when materials containing deca-BDEs are burned and the availability of other non-PBDE flame-retardant compounds [29]. Despite the worldwide reduction in production and use, it is widely believed that like other persistent organic pollutants, long-term exposure will continue long after PBDE production has ceased. This will occur through both direct exposure to emissions from PBDE-containing products that remain in use and by indirect dietary exposure occurring as a consequence of these emissions escaping into the outdoor environment and biomagnifying in the food chain [30].

The association between developmental exposure to PBDEs and neurodevelopment has been extensively studied using animal models. In this review, we highlight key animal studies but focus on the accumulating evidence in humans. PubMed and Google Scholar searches were performed in November 2013 with the search terms Polybrominated Diphenyl Ethers OR PBDE OR BDE AND neurodevelopment. We included all full-text articles in English published prior to November 2013. References of all articles were reviewed to identify additional matching articles.

\section{Toxicology}

Detailed reviews of animal evidence on the effects of developmental exposure to PBDEs on neurodevelopment are available $[31 \bullet, 32,33]$. In brief, Eriksson and colleagues conducted a series of experiments exposing neonatal mice to individual PBDEs (including BDE-47, BDE-99, BDE-153, BDE-183, BDE-203, BDE-206, and BDE-209) on either postnatal day 3, 10 , or 19 . They observed that with some variation between congeners, exposure was associated with changes in spontaneous behavior (increased locomotor activity consistent with hyperactivity), habituation, learning, and memory functions [34-38]. The neurodevelopmental effects were apparent when exposure occurred within the period of rapid brain growth corresponding to the first 2 weeks after birth (analogous to the human perinatal period beginning during the third trimester and continuing through the first 2 years of life) [35, 39]. Effects did not vary by sex or mouse strain [40] and appeared to worsen with age, such that PBDE-related effects on altered spontaneous behavior and reduced habituation capabilities were more pronounced as the animals aged [34, 36-38]. Effects on neurodevelopment were corroborated by other investigators who found that in mice, perinatal PBDE exposure was associated with impaired learning and poorer functioning on memory tasks [41-44], altered locomotor activity, increased hyperactivity [45-49], and increased impulsivity, particularly in adult animals [50]. In rats, similar detrimental effects on attention and learning were also observed $[43,51]$.

\section{Epidemiology: Summary of the Evidence}

Only a small number of studies have examined the relationship between prenatal and childhood PBDE exposure and neurodevelopment in humans (Table 1). Among the eight studies identified, three are from Europe (one from the

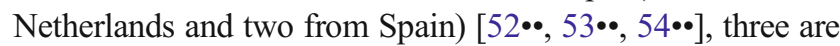
from the US (New York, California, and North Carolina)

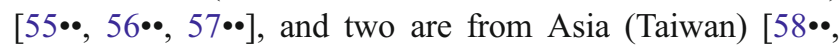
59••]. The studies examining the impact of prenatal PBDEs and neurodevelopment during childhood are necessarily longitudinal while those examining the impact of childhood exposure on neurodevelopmental indices are cross-sectional. The prospective studies identified had a size range of 36-288 participants.

In the Netherlands, Roze and colleagues measured five BDE congeners (not including BDE-209, the fully brominated congener that is the predominant component of the decaBDE formulation) in 62 maternal blood samples collected from women during pregnancies occurring in 2001 and 2002 [54••]. PBDE concentrations in maternal blood are highly correlated with cord blood concentrations [60]. They compared PBDE concentrations in maternal blood to a large battery of motor, cognitive, and behavioral tests in children aged 5-6 years. They reported significant correlations between some individual BDE congeners and impaired fine manipulative abilities (BDE-154) and sustained attention (BDE-47, -99, -100), but also significant correlations between selective BDE congeners and improved selective attention and internalizing behavior. The number of comparisons conducted and the limited adjustment for relevant confounders are important limitations of this analysis.

In Spain, Gascon and colleagues measured 19 BDE congeners (not including BDE-209) in cord and peripheral blood from 88 children born in 1997-1998 and in peripheral blood samples from 156 additional children at age 4 years [53••]. They evaluated the association with motor, cognitive, and behavioral outcomes at age 4 years. They analyzed only BDE-47 (as a dichotomous measure) because it was the dominant congener and the only one detected in over $50 \%$ of samples. Detectable levels of childhood BDE-47 exposure were associated with increased risk of attention (but not hyperactivity) symptoms and poorer social competency scores. Detectable levels of prenatal and childhood BDE-47 were both associated with lower cognitive and motor function, 
Table 1 Summary of epidemiologic evidence

\begin{tabular}{|c|c|c|c|}
\hline $\begin{array}{l}\text { Author/Year } \\
\text { [Location] }\end{array}$ & Exposure Information & $\begin{array}{l}\text { Outcome Information } \\
\text { (age at assessment) }\end{array}$ & Key Findings \\
\hline \multirow{12}{*}{$\begin{array}{l}\text { Roze et al. } 2009 \text { [54] } \\
\text { [Netherlands] }\end{array}$} & \multirow{5}{*}{$\begin{array}{l}\text { Matrix: } \\
\text { maternal blood during } \\
\text { 35th wk of pregnancy } \\
(n=62) \\
\text { Collection: } 2001-2002 \\
\text { PBDEs measured: } 47 \text {, } \\
99,100,153,154\end{array}$} & Movement ABC (5-6) ${ }^{\mathrm{a}}$ & -- \\
\hline & & $\begin{array}{l}\text { Touwen's age-specific neurologic } \\
\text { examination }(5-6)^{\mathrm{a}}\end{array}$ & $\begin{array}{l}\text { correlation with worsening fine } \\
\text { manipulative ability (BDE-154) }\end{array}$ \\
\hline & & $\begin{array}{l}\text { Developmental Coordination Disorder } \\
\text { Questionnaire, DCD-Q }(5-6)^{\mathrm{a}}\end{array}$ & -- \\
\hline & & $\begin{array}{l}\text { Wechsler Preschool and Primary Scale } \\
\text { of Intelligence, revised, WPPSI-R }(5-6)^{\mathrm{b}}\end{array}$ & -- \\
\hline & & $\begin{array}{l}\text { Neuropsychological Assessment--2nd } \\
\text { ed., NEPSY-II }(5-6)^{\text {b }}\end{array}$ & -- \\
\hline & & $\begin{array}{l}\text { Rey's Auditory Verbal Learning Test, } \\
\text { AVLT }(5-6)^{\text {b }}\end{array}$ & $\begin{array}{l}\text { correlation w/ worse verbal memory } \\
\text { (BDE-153); correlation w/ worse } \\
\text { sustained attention (BDE-47); } \\
\text { correlation w/ worse sustained } \\
\text { attention (BDE-47, 99, 100), } \\
\text { correlation with better selective } \\
\text { attention (BDE-47) }\end{array}$ \\
\hline & & Child Behavior Checklist, CBCL (5-6) & $\begin{array}{l}\text { correlation } w / \text { fewer total and } \\
\text { internalizing behavior problems (BDE- } \\
99,100)\end{array}$ \\
\hline & & CBCL Teacher's Report Form $(5-6)^{\mathrm{C}}$ & $\begin{array}{l}\text { correlation } w / \text { fewer internalizing } \\
\text { behavior problems (BDE-47, 99, 100) }\end{array}$ \\
\hline & & $\begin{array}{l}\text { ADHD questionnaire by Scholte et al. } \\
2004(5-6)^{c}\end{array}$ & -- \\
\hline & & $\begin{array}{l}\text { McCarthy Scales of Children's Abilities } \\
\text { (MSCA) adapted to the Spanish } \\
\text { population }(4)^{c}\end{array}$ & -- \\
\hline & & $\begin{array}{l}\text { The California Preschool Social } \\
\text { Competence Scale }(4)^{c}\end{array}$ & $\begin{array}{l}\text { correlation with worsening fine } \\
\text { manipulative ability (BDE-154) }\end{array}$ \\
\hline & & $\begin{array}{l}\text { ADHD Criteria of the Diagnostic and } \\
\text { Statistical Manual of Mental Disorders } \\
\text { 4th Ed }(4)^{c}\end{array}$ & ( \\
\hline $\begin{array}{l}\text { Gascon et al. } 2011 \text { [53] } \\
\text { [Spain] }\end{array}$ & $\begin{array}{l}\text { Matrix: } \\
\text { cord blood }(n=88) \\
\text { peripheral blood at } 4\end{array}$ & $\begin{array}{l}\text { McCarthy Scales of Children's Abilities } \\
\text { (MSCA) adapted to the Spanish } \\
\text { population }(4)^{a, b}\end{array}$ & -- \\
\hline & yrs $(n=288)$ & $\begin{array}{l}\text { The California Preschool Social } \\
\text { Competence Scale }(4)^{c}\end{array}$ & $\begin{array}{l}\text { association w/poor social } \\
\text { competence (BDE-47 at age } 4)\end{array}$ \\
\hline & $\begin{array}{l}\text { Collection: } 1997-1998 \\
\text { PBDEs measured: } 12- \\
\text { 13, 32, 17, 28-33,47, } \\
\text { 100, 119, 99, 116, 85, } \\
\text { 126, 155, 153, 183, 66, } \\
71,154,138 \text {, and } 190\end{array}$ & $\begin{array}{l}\text { ADHD Criteria of the Diagnostic and } \\
\text { Statistical Manual of Mental Disorders } \\
\text { 4th Ed }(4)^{c}\end{array}$ & $\begin{array}{l}\text { association w/ attention deficit } \\
\text { symptoms (BDE-47 at age 4) }\end{array}$ \\
\hline $\begin{array}{l}\text { Gascon et al. } 2012 \text { [52] } \\
\text { [Spain] }\end{array}$ & $\begin{array}{l}\text { Matrix: } \\
\text { breast milk }(n=209) \\
\text { Collection: } 2004-2008 \\
\text { *PBDEs measured: } \\
\text { 17, 28, 47, 66, 71, 85, } \\
99,100,138,153,154, \\
183,190,209\end{array}$ & Bayley Scales $(1-1.5)^{\mathrm{a}, \mathrm{b}}$ & $\begin{array}{l}\text { association w/ lower mental } \\
\text { developmental index (BDE-209) }\end{array}$ \\
\hline \multirow[t]{2}{*}{$\begin{array}{l}\text { Herbstman et al. } 2012 \\
{[56]} \\
{[\mathrm{NY}, \text { USA] }}\end{array}$} & $\begin{array}{l}\text { Matrix: } \\
\text { cord blood }(n=210) \\
\text { Collection: } 2001-2002\end{array}$ & Bayley Scales--2nd Ed. $(1,2,3)^{a, b}$ & $\begin{array}{l}\text { association w/ lower psychomotor at } \\
1 \mathrm{yr}(\mathrm{BDE}-100), \mathrm{w} / \text { mental } \\
\text { developmental index scores at } 2 \mathrm{yrs} \\
(\mathrm{BDE}-47,99,100) \text { and 3yrs (BDE-100) }\end{array}$ \\
\hline & $\begin{array}{l}\text { PBDEs measured: } \\
47,85,99,100,153 \\
154, \text { and } 183\end{array}$ & $\begin{array}{l}\text { Wechsler Preschool and Primary Scale } \\
\text { of Intelligence, revised, WPPSI-R }(4,6)^{b}\end{array}$ & $\begin{array}{l}\text { association w/ lower full scale IQ at } \\
4 \mathrm{yrs}(\mathrm{BDE}-47,99,100) \text { and lower } \\
\text { verbal IQ at } 4 \mathrm{yrs}(\mathrm{BDE}-47,99)\end{array}$ \\
\hline
\end{tabular}




\begin{tabular}{|c|c|c|c|}
\hline \multirow[t]{2}{*}{$\begin{array}{l}\text { Shy et al. } 2011 \text { [59] } \\
\text { [Taiwan] }\end{array}$} & \multirow{2}{*}{$\begin{array}{l}\text { Matrix: } \\
\text { cord blood }(n=36) \\
\text { Collection: } 2007-2008 \\
\text { PBDEs measured: } \\
\text { 15, 28, 47, 49, 99, 100, } \\
153,154,183,196, \\
\text { and } 197\end{array}$} & Bayley Scales--3rd Ed (8mo-1 yr) $)^{a, b}$ & $\begin{array}{l}\text { association w/ higher cognitive scores } \\
\text { (BDE-15, 99, 197, and sum of } \\
\text { congeners) }\end{array}$ \\
\hline & & $\begin{array}{l}\text { Bayley Scales--Parent-report } \\
\text { questionnaires }(8 \mathrm{mo}-1 \mathrm{yr})^{\mathrm{c}}\end{array}$ & $\begin{array}{l}\text { association w/ worse adaptive } \\
\text { behavior (BDE-28, 99, 154, } 183 \text { and } \\
\text { sum of congeners) }\end{array}$ \\
\hline $\begin{array}{l}\text { Hoffman et al. } 2012 \\
{[57]} \\
{[N C, \text { USA] }}\end{array}$ & $\begin{array}{l}\text { Matrix: } \\
\text { breast milk }(\mathrm{n}=222) \\
\text { Collection: } 2001-2005 \\
\text { PBDEs measured: } \\
28,47,99,100 \text {, and } \\
153\end{array}$ & $\begin{array}{l}\text { Infant-Toddler Social and Emotional } \\
\text { Assessment }(1-2)^{c}\end{array}$ & $\begin{array}{l}\text { association w/ more externalizing } \\
\text { problems (BDE-99, 100), w/ worse } \\
\text { activity/impulsivity scores (BDE-28, } \\
\quad 47,99,100, \text { and sum) }\end{array}$ \\
\hline \multirow[t]{2}{*}{$\begin{array}{l}\text { Chao et al. } 2011[58] \\
\text { [Taiwan] }\end{array}$} & \multirow{2}{*}{$\begin{array}{l}\text { Matrix: } \\
\text { breast milk }(n=70) \\
\text { Collection: } 2007-2010 \\
\text { *PBDEs measured: } \\
28,47,99,100,153, \\
154,183,196,197, \\
203,206,207,208, \\
\text { and } 209\end{array}$} & $\begin{array}{l}\text { Bayley Scales--3rd Ed } \\
(8 \mathrm{mo}-1 \mathrm{y})^{\mathrm{a}, \mathrm{b}}\end{array}$ & $\begin{array}{l}\text { association w/worse cognitive scores } \\
\text { (BDE-209); association w/improved } \\
\text { language (BDE-196) }\end{array}$ \\
\hline & & $\begin{array}{l}\text { Bayley Scales--Parent-report } \\
\text { questionnaires }(8 \mathrm{mo}-1 \mathrm{yr})^{c}\end{array}$ & -- \\
\hline \multirow[t]{9}{*}{$\begin{array}{l}\text { Eskanazi et al. } 2013 \\
{[55]} \\
{[\mathrm{CA}, \text { USA] }}\end{array}$} & \multirow{9}{*}{$\begin{array}{l}\text { Matrix: } \\
\text { maternal blood during } \\
\text { pregnancy or at } \\
\text { delivery ( } n=279) \text {; } \\
\text { peripheral blood at } \\
\text { age } 7 \text { yrs ( } n=272) \\
\text { Collection: } 1999-2000 \\
\text { (cord) } \\
\text { PBDEs measured: } \\
17,28,47,66,85,99, \\
100,153,154, \text { and } 183\end{array}$} & $\begin{array}{l}\text { Child Behavior Checklist, } \mathrm{CBCL}(5)^{\mathrm{C}} \\
\text { Conners' Kiddie Continuous } \\
\text { Performance Test }(5)^{\mathrm{c}}\end{array}$ & $\begin{array}{l}\text {-- } \\
\text { association w/ more errors of } \\
\text { omission and ADHD confidence index } \\
\text { (sum of maternal } 47,99,100 \text {, and } \\
\text { 153) }\end{array}$ \\
\hline & & $\begin{array}{l}\text { Conners' ADHD/DSM-IV Scales, } \\
\text { maternal report }(7)^{\mathrm{c}}\end{array}$ & $\begin{array}{l}\text { association w/ADHD index and DSM- } \\
\text { IV total (sum of maternal } 47,99,100, \\
\text { and } 153 \text { ) }\end{array}$ \\
\hline & & $\begin{array}{l}\text { Conners' ADHD/DSM-IV Scales, teacher } \\
\text { report }(7)^{\mathrm{c}}\end{array}$ & $\begin{array}{l}\text { association w/ADHD index, DSM-IV } \\
\text { total, inattentive subscale (sum of all } \\
\text { child } 47,99,100 \text {,and } 153 \text { ) }\end{array}$ \\
\hline & & $\begin{array}{l}\text { Behavior Assessment System for } \\
\text { Children, 2nd edition }(7)^{\mathrm{C}}\end{array}$ & $\begin{array}{l}\text { association w/hyperactivity and } \\
\text { attention problems (sum of child } 47 \text {, } \\
99,100 \text {,and } 153 \text { ) }\end{array}$ \\
\hline & & $\begin{array}{l}\text { McCarthy Scales of Children's Abilities } \\
(5)^{\mathrm{a}}\end{array}$ & $\begin{array}{l}\text { association w/ worse pegboard } \\
\text { performance (non-dominant hand), } \\
\text { worse finger tap (dominant hand) } \\
\text { (sum of maternal } 47,99,100 \text {, and } \\
\text { 153) }\end{array}$ \\
\hline & & $\begin{array}{l}\text { McCarthy Scales of Children's Abilities } \\
(7)^{\mathrm{a}}\end{array}$ & $\begin{array}{l}\text { association w/ worse pegboard } \\
\text { performance (non-dominant hand) } \\
\text { (sum of maternal } 47,99,100 \text {, and } \\
\text { 153) }\end{array}$ \\
\hline & & Peabody Picture Vocabulary Test $(5)^{\mathrm{b}}$ & -- \\
\hline & & $\begin{array}{l}\text { Wechsler Preschool and Primary Scale } \\
\text { of Intelligence, 3rd edition }(5)^{\mathrm{b}}\end{array}$ & -- \\
\hline & & $\begin{array}{l}\text { Wechsler Intelligence Scale for } \\
\text { Children-Fourth Edition }(7)^{\mathrm{b}}\end{array}$ & $\begin{array}{l}\text { association w/ lower verbal } \\
\text { comprehension IQ (sum of maternal } \\
47,99,100 \text {, and } 153 \text { ); full scale IQ and } \\
\text { processing speed (sum of child } 47,99 \text {, } \\
100,153 \text { ) }\end{array}$ \\
\hline
\end{tabular}

${ }^{\mathrm{a}}$ Motor domain

${ }^{\mathrm{b}}$ Cognitive domain

${ }^{\mathrm{c}}$ Behavioral domain

*Deca-BDE measured 
although the associations were not statistically significant. In a follow-up study conducted in 2004-2008, the same group measured seven BDE concentrations including BDE-209 in colostrum from 290 women just after delivery and assessed neurodevelopment at 14 months (on average) using the Bayley Scales [52••]. Individual BDE congeners as well as the sum of the seven BDEs were associated with worse scores on the mental developmental index but not with the psychomotor developmental index. The effects were strongest for BDE-209, which is often not measured or detectable in biologic matrices with lower lipid concentrations (e.g., blood).

In New York City, where exposures are, on average, an order of magnitude higher than those reported in the

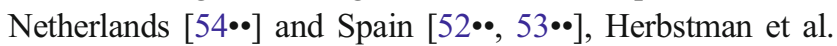
measured seven BDEs (not including BDE-209) in cord blood collected in 2001-2002 [56••]. They evaluated the association between prenatal PBDEs and neurodevelopment among 152 children at age 1-4 years and at age 6 years. In this lower Manhattan-based cohort, exposure to individual BDE congeners was negatively associated with various indices of mental and psychomotor development assessed from 1 to 3 years, as well as with full-scale, verbal, and performance intelligence quotient (IQ) assessed at 4 and 6 years.

In a small study, Shy et al. measured 11 PBDEs (not including BDE-209) in cord blood from 36 neonates in Taiwan [59••]. They reported associations between exposure to the sum of 11 BDEs and higher cognitive scores and worse adaptive behavior measured by the Bayley Scales at age 8 months to 1 year; however, their small sample size warrants a cautious interpretation.

In a study in North Carolina, Hoffman et al. measured BDE-47, -99 , and -100 concentrations in postpartum breast milk collected between 2001 and 2005 and social and emotional development in 222 children at age 2 years [57••]. They observed a positive dose-dependent relationship between the sum of PBDE concentrations and increased externalizing behavior problems, specifically activity and impulsivity behavior. While this study examined children who were too young for a clinical diagnosis, similar activity and impulsivity behaviors displayed in later childhood would be expected among children with an established ADHD diagnosis [61].

Chao et al. investigated PBDE exposure in postpartum

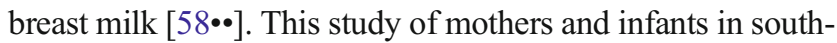
ern Taiwan enrolled between 2000 and 2001, noted a significant correlation with BDE-209 body concentrations and worse cognitive abilities in infants at age 1 year as measured using the Bayley-III. In addition, this study described a significant correlation between BDE-100 and better language skills at age 1 year as measured on the Bayley-III.

In a recent study of California children, Eskenazi and colleagues reported associations between both prenatal and childhood PBDE exposure with neurodevelopmental deficits, specifically in areas of cognition, attention, and motor function $[55 \bullet \bullet$. The study measured PBDEs in maternal serum before birth or at delivery between October 1999 and October 2000, as well as in children's serum at age 7 years. This cohort study used the sum of the levels of BDE-47, -99 , -100 , and -153 as the measure of exposure. Children's neurodevelopment skills were analyzed at age 5 years and at age 7 years using a number of neurodevelopmental tests. They found that both the 5 - and 7-year-old age groups demonstrated impaired attention and exhibited poorer fine motor coordination in association with maternal and childhood PBDE exposure; only the 7-year-old age group exhibited significant decrements in verbal and full-scale IQ with increasing maternal and childhood PBDE exposure. Interestingly, developmental and behavioral associations between cognition, motor function, and attention with both maternal and child PBDE exposures were found, even though only weak correlations existed between maternal serum PBDE concentrations and corresponding child serum PBDE concentrations.

\section{Epidemiology: Interpretation of the Evidence}

The majority of the epidemiologic studies published to date report associations between early-life concentrations of PBDEs (prenatal, at birth, or during early childhood) and worse neurodevelopmental outcomes (both cognitive and behavioral). However, among the published studies, there are a number of inter-related, non-mutually exclusive, methodological discrepancies enumerated below. In addition, when evaluating the weight of the evidence from the scientific literature, publication bias cannot be ruled out, as "positive" findings are more likely to be published than "negative" findings [62].

First, PBDE exposure is known to differ geographically, such that body concentrations in North America are, on average, an order of magnitude higher than those reported in Europe or Asia [16•]. This geographic difference is likely the result of differing product marketing histories, product usage, and regulatory policies regarding flame retardants [18]. Therefore, neonates with "high" exposure in a European-based study are likely to have equivalent concentrations of PBDEs as those who are classified as having "low" exposure in a North American-based study. Even within North America, large inter-individual differences in body concentrations are observed. For example, using the National Health and Nutrition Examination Survey (NHANES), Zota et al. examined serum PBDE concentrations by US region and observed a wide range of exposure within and across regions, with higher concentrations of PBDE among Californians in comparison with other US regions [21]. They speculate that this is because of the California-based TB-117 regulation, which is a 1975 performance-based furniture flammability standard. However, it is not clear that manufacturers make products for California consumption different than products 
for use throughout the rest of the country. Formal analyses of geographic differences are scarce.

Second, PBDE exposure likely differed temporally in different world areas. For example, from 1986 to 2006, PBDEs detected in falcon eggs collected in California increased [63]. In addition, a meta-analysis of human exposure to PBDEs demonstrates a marked increase in PBDEs measured in human blood, milk, and tissue from 1970 to 2004 [16•]. It is also possible that after a phase-out, a decrease in PBDE exposure will be observed. This was observed in Sweden where PBDEs measured in breast milk increased from 1996 to 1998 and then decreased from 1998 to 2001 following the phase-out of PBDEs in the EU in 1997 [64]. In the US, this relationship was examined using PBDEs measured in serum from three NHANES survey periods: 2003/04, 2005/06, and 2007/08 [65•]. Sjodin et al. found that overall, lower PBDE concentrations were observed in 2007/08 compared with 2003/04, although these differences were not statistically different. They speculate that this may be because not enough time has passed since the phase-out and many US households likely still possess furniture and other PBDE-containing products.

Third, a critical difference between studies concerns the congeners measured. Because BDE-209 is ubiquitous in dust, it was not detectable in study samples over 'background' laboratory exposure in earlier studies. New laboratory methods have been developed to minimize contamination by 'background' BDE exposure, enabling better quantification (with lower limits of detection) of BDE-209 in biological samples [66, 67]. Different congeners (specifically BDE-209 in comparison with the lower brominated congeners that are associated with the penta- and octa-BDE mixtures) may elicit different neurodevelopmental effects. The direct comparison of studies that have and have not included the measurement of BDE-209 is difficult.

Fourth, differences in the ages to which the children were followed and/or tested as well as the neurodevelopmental indices used to measure either cognition or specific domains of child behavior may account for some discrepancies between reports. There are neurodevelopmental tests that are not translated into the languages required for use in the different international settings. The majority of the tests cited above are available in English with validated translations in Spanish. More language options, especially tests with Asian language options need to be available for comparability in the future. It is also worth noting that some translations are region specific. For example, the Wechsler Intelligence Scale for Children, Fourth Edition has been translated and validated for US Spanish, which, in some cases, may or may not be appropriate for Spanish spoken in other countries [68]. In addition, different versions of the same instrument may or may not provide equivalent information. An example of this incongruity occurred with Bayley version II and Bayley version III for which scores of the two tests are not directly comparable. Finally, the Bayley instrument used in children aged 12 months may not be sensitive enough to detect PBDEassociated neurodevelopmental deficits.

Furthermore, the proper adjustment for confounders may be critical to demonstrate effects of PBDE exposure on neurodevelopment. Studies have measured different potential confounding factors and/or treated them differently in their analyses. Moreover, smaller studies have less statistical power precluding the inclusion of many confounders in their multivariate models. Finally, the choice of statistical model (which may, in part, be related to sample size/power) may impact the comparability of the studies. For example, Roze et al. present correlation coefficients adjusted for sex, socioeconomic status, and score on the Home Observation for Measurement of the Environment (HOME) questionnaire [54・•]. In comparison, Eskenazi et al. present estimates and confidence intervals from multiple linear regression analyses adjusted for child's age, sex, HOME score, father living with family, handedness, location of testing, whether the child attended preschool, and maternal years in the US before giving birth [55••].

Despite these differences between studies, the preponderance of the evidence supports that early-life exposure to PBDEs is detrimental to child neurodevelopment.

\section{Possible Mechanisms}

While the precise mechanism of action of PBDEs on neurodevelopment is not known, at least two, non-mutually exclusive, mechanisms of action have been proposed. PBDEinduced neurotoxicity via thyroid hormone disruption has been studied in both laboratory and epidemiologic settings. This mechanism has been proposed, in part because of the structural similarity between PBDEs and thyroxine (T4). T4 and related thyroid hormones are critical for normal brain development, thereby providing a reasonable link between PBDE exposure and neurotoxicity. In addition, there may be a direct effect of PBDEs on glial and neuronal cells in the brain. Animal data suggest that deficits in thyroid hormones result in abnormal proliferation of axons and dendrites, synapse formation, gliogenesis and myelination in the cerebrum and cerebellum, and abnormal cellular proliferation in the cerebellum [69]. In humans, deprivation of thyroid hormone either in utero or during the perinatal period result in deficits in cognitive and motor function [70]. However, brain development does not stop at birth, but likely continues through the first two decades of postnatal life. This developmental period involves reorganization in the human cortex [71]. Although this reorganization begins prenatally, continued dendritic and axonal growth, synapse production, neuronal and synaptic pruning, and changes in neurotransmitter sensitivity continue to occur after birth [72]. Both thyroid hormone excesses and 
deficiencies are thought to be detrimental throughout this developmental window [73]. Despite the clear evidence that thyroid hormones are critical for brain development, the mode of action of thyroid hormones on cellular and molecular targets within the central nervous system is still largely unknown [74].

\section{Thyroid Function}

Because of its structural similarity to the thyroid hormone T4, PBDE exposure likely disrupts thyroid hormones. In vitro models have shown that PBDE congeners, as well as their hydroxylated metabolites have the potential to bind to thyroid hormone receptors $[75,76]$ and animal models indicate that PBDEs may have a direct effect on the thyroid gland $[44,77]$.

There is much interest in thyroid hormone disruption following neonatal PBDE exposure because of the brain's dependence on carefully regulated levels of thyroid hormones for normal development. In studies where rodents were exposed perinatally to specific PBDE congeners or the PBDE commercial mixture DE-71, most identified a negative relationship between exposure and circulating levels of T4 [51, 78-83] and triiodothyronine (T3), the biologically active form of T4 [80, 81, 84] but little evidence of an effect on thyroidstimulating hormone (TSH), which regulates the production of T4. Because of the similarity in the physiology of gestation between sheep and humans, a recent study examined the effects of lambs exposed prenatally to PBDEs and also found inverse associations with both $\mathrm{T} 4$ and $\mathrm{T} 3$ [85]. In humans, the number of studies is small and the evidence is inconsistent. Some studies have observed no association between indicators of prenatal PBDE exposure and thyroid hormones [84, $86,87]$, some found some evidence of an inverse association $[85,88,89]$, and one study observed a positive association [54••]. Differences in PBDE exposure levels and the timing and type of thyroid hormones measured may account for some of these differences; however, the full explanation for the discrepancies between human studies and between observations in animal models and humans is largely unknown.

While most studies of developmental PBDE exposure focused on the prenatal and early postnatal periods, PBDE exposure during childhood may also influence thyroid hormones. Gascon and colleagues investigated the association between PBDE exposure measured at age 4 years and thyroid hormones and identified a positive association with T3 [53••]. Both animal and human studies have found that adults are also susceptible to thyroid dysregulation following PBDE exposure; however, the direction of these effects varies by study. In adult mice, PBDE exposure is most often associated with lower T4 and no effect on TSH [90-92]. In humans, some studies of adults report that PBDEs are associated with higher levels of T4, T3, and/or TSH [93-95] and others report no observed effects [96, 97]. Pregnant women are a subgroup of adults that may have distinct susceptibility to thyroid disruption from PBDE exposure. This is because of the increased demand that pregnancy places on the thyroid hormone system, as mothers are the sole provider of thyroid hormone to the fetus before gestational week 16 when the fetal hypothalamic-pituitary axis matures [98]. In pregnant sheep, there was no reported association between PBDE exposure and thyroid hormones [99]. In humans, however, the results are inconsistent, with one study of PBDEs in pregnant women reporting lower TSH [100] and another reporting no association with TSH [85], one reporting higher T4 and T3 [101] and another reporting lower $\mathrm{T} 3$ and T4 [85] and yet another reporting no association with $\mathrm{T} 4$ [100].

\section{Direct Effects on Brain Cells}

As reviewed previously $[31 \bullet, 32]$, there are three proposed mechanisms by which PBDE exposure may result in direct effects on brain cells, specifically neuronal and glial cells. Oxidative stress in response to PBDE exposure has been observed to cause neuronal death owing to apoptosis [32, 44, 102-104]. Additionally, PBDEs and PBDE metabolites have been shown to disrupt vital intracellular and extracellular signaling mechanisms in the brain including calcium homeostasis and protein kinase C [105]. Calcium levels require exquisite regulation and balance in the brain because calcium is essential in early brain development and influences almost every biochemical and physiologic process of the neuron [106]. In particular, calcium is involved in the opposing processes of brain growth and degeneration through the mechanisms of synaptic plasticity, cell excitability, and synaptic transmission [106]. It is therefore logical that even the smallest deviations in timing of calcium release and calcium level in response to PBDE exposure may result in substantial neurodevelopmental changes. Finally, Schreiber and colleagues found that exposing human neuroprogenitor cells to PBDEs affected cell migration and differentiation into neurons and oligodendrocytes [107]. Because cell migration and neurogenesis occur mainly during the prenatal period and oligodendrogenesis occurs postnatally, the authors provide evidence that both pre- and postnatal PBDE exposures may influence neurodevelopment.

\section{Future Directions for Research and Conclusions}

Longitudinal cohort studies are the "gold standard" in environmental epidemiology, where randomized clinical trials are not often possible and/or ethical. There have been a number of 
longitudinal birth cohort studies that have demonstrated neurodevelopmental effects of early-life PBDE exposure $[52 \bullet \bullet, 53 \bullet \bullet, 54 \bullet, 55 \bullet \bullet, 56 \bullet, 57 \bullet \bullet, 58 \bullet \bullet, 59 \bullet \cdot]$. However, these studies are time consuming and expensive and many are relatively small in size. This limits the types of statistical analyses possible and also the strength of the conclusions that can be drawn from the results. Therefore, additional larger scale longitudinal studies would be informative and could fill in the data gaps and alleviate uncertainty surrounding this association. In addition, more studies measuring BDE-209 would be helpful to discriminate across congeners (assuming that there are some that may be less toxic than others). Finally, studies that examine the impact of the hydroxylated metabolites of PBDEs may be informative, as evidence suggests that the neurotoxic potential is higher for the hydroxylated metabolites than for the parent compounds [105]. While inroads have been made to identify the mechanism of action and a number of potential mechanisms have been tested, it is not clear how these mechanisms interact with one another and whether or not observations in animals are also operating in humans. As such, questions still remain as to exactly how early-life or childhood PBDE exposure may impact neurodevelopmental indices. A complete understanding of whether and how the various BDE congeners and hydroxylated metabolites elicit neurotoxic effects can be informative in terms of developing strategies to mitigate their impact.

By the end of 2013, the companies that produced penta-, hexa-, octa-, and deca-BDEs have either agreed to discontinue the use of these compounds (North America and Europe) [28•] or have reduced their production (China) [29]. However, PBDE exposure will likely continue well into the future, as PBDE-containing products are infrequently replaced [65•]. In addition, other substitute compounds are now being used to meet regulatory fire standards. Whether and how exposure to these replacement compounds in new products interacts with PBDEs in products currently in use has not been examined. Further, as PBDE-containing products are discarded or recycled over time, the post-consumer impact on the environment and ultimately human health is not well understood. Outside of these uncertainties, the weight of the epidemiologic evidence published to date supports that early-life exposure to PBDEs is detrimental to child neurodevelopment.

\section{Compliance with Ethics Guidelines}

Conflict of Interest Julie B. Herbstman and Jennifer K. Mall declare that they have no conflict of interest.

Human and Animal Rights and Informed Consent This article does not contain any studies with human or animal subjects performed by any of the authors.

\section{References}

Papers of particular interest, published recently, have been highlighted as:

- Of importance

-. Of major importance

1. O'Rahilly R, Muller F. Significant features in the early prenatal development of the human brain. Ann Anat. 2008;190: $105-18$.

2. Greydanus DE, Patel DR, Pratt HD. Neurodevelopmental disabilities: preface. Pediatr Clin N Am. 2008;55:xi-xii.

3. America's Children. Key National Indicators of Well-Being. Washington, DC: U.S. Government Printing Office; 2011.

4. Bloom B, Cohen RA, Freeman G. Summary health statistics for U.S. children: National Health Interview Survey, 2010. National Center for Health Statistics. Vital Health Stat 10. 2011;250:1-10.

5. Aguiar A, Eubig PA, Schantz SL. Attention deficit/hyperactivity disorder: a focused overview for children's environmental health researchers. Environ Health Perspect. 2010;118:1646-53.

6. Rowland AS, Lesesne CA, Abramowitz AJ. The epidemiology of attention-deficit/hyperactivity disorder (ADHD): a public health view. Ment Retard Dev Disabil Res Rev. 2002;8:162-70.

7. Pastor PN, Reuben CA. Diagnosed attention deficit hyperactivity disorder and learning disability: United States, 2004-2006. Vital Health Stat. 2008;10:1-14.

8. Kessler RC, Adler LA, Barkley R, Biederman J, Conners CK, et al. Patterns and predictors of attention-deficit/hyperactivity disorder persistence into adulthood: results from the national comorbidity survey replication. Biol Psychiatry. 2005;57:1442-51.

9. Pelham WE, Foster EM, Robb JA. The economic impact of attention-deficit/hyperactivity disorder in children and adolescents. J Pediatr Psychol. 2007;32:711-27.

10. Birnbaum LS, Staskal DF. Brominated flame retardants: cause for concern? Environ Health Perspect. 2004;112:9-17. Description of PBDEs as an emerging class of compounds of concern for neurodevelopment.

11. Babrauskas V, Blum A, Daley R, Birnbaum L. Flame retardants in furniture foam: benefits and risks. Fire Saf Sci. 2011;10:265-78.

12. Shaw SD, Blum A, Weber R, Kannan K, Rich D, et al. Halogenated flame retardants: do the fire safety benefits justify the risks? Rev Environ Health. 2010;25:261-305.

13. Darnerud PO, Eriksen GS, Johannesson T, Larsen PB, Viluksela M. Polybrominated diphenyl ethers: occurrence, dietary exposure, and toxicology. Environ Health Perspect. 2001;109 Suppl 1:49-68.

14. Palm A, Cousins IT, Mackay D, Tysklind M, Metcalfe C, et al. Assessing the environmental fate of chemicals of emerging concern: a case study of the polybrominated diphenyl ethers. Environ Pollut. 2002;117:195-213.

15. Geyer HJ, Schramm K-W, Darnerud PO, Aune M, Feicht EA, et al. Terminal elimination half-lives of the brominated flame retardants TBBPA, HBCD, and lower brominated PBDEs in humans. Organohalogen Compd. 2004;66:386772.

16. Hites RA. Polybrominated diphenyl ethers in the environment and in people: a meta-analysis of concentrations. Environ Sci Technol. 2004;38:945-56. Meta-analysis of studies describing the temporal and geographic trends in PBDE exposure in the environment and people.

17. Sjodin A, Wong LY, Jones RS, Park A, Zhang Y, et al. Serum concentrations of polybrominated diphenyl ethers (PBDEs) and polybrominated biphenyl (PBB) in the United States population: 2003-2004. Environ Sci Technol. 2008;42:1377-84. 
18. Frederiksen M, Vorkamp K, Thomsen M, Knudsen LE. Human internal and external exposure to PBDEs: a review of levels and sources. Int J Hyg Environ Health. 2009;212:109-34.

19. Lorber M. Exposure of Americans to polybrominated diphenyl ethers. J Expo Sci Environ Epidemiol. 2008;18:2-19.

20. Wang J, Ma YJ, Chen SJ, Tian M, Luo XJ, et al. Brominated flame retardants in house dust from e-waste recycling and urban areas in South China: implications on human exposure. Environ Int. 2010;36:535-41.

21. Zota AR, Rudel RA, Morello-Frosch RA, Brody JG. Elevated house dust and serum concentrations of PBDEs in California: unintended consequences of furniture flammability standards? Environ Sci Technol. 2008;42:8158-64.

22. Jones-Otazo HA, Clarke JP, Diamond ML, Archbold JA, Ferguson $\mathrm{G}$, et al. Is house dust the missing exposure pathway for PBDEs? An analysis of the urban fate and human exposure to PBDEs. Environ Sci Technol. 2005;39:5121-30.

23. Lunder S, Hovander L, Athanassiadis I, Bergman A. Significantly higher polybrominated diphenyl ether levels in young U.S. children than in their mothers. Environ Sci Technol. 2010;44:525662.

24. Rose M, Bennett DH, Bergman A, Fangstrom B, Pessah IN, et al. PBDEs in 2-5 year-old children from California and associations with diet and indoor environment. Environ Sci Technol. 2010;44: 2648-53.

25. Toms LM, Sjodin A, Harden F, Hobson P, Jones R, et al. Serum polybrominated diphenyl ether (PBDE) levels are higher in children (2-5 years of age) than in infants and adults. Environ Health Perspect. 2009; 117:1461-5.

26. Landrigan PJ, Goldman LR. Protecting children from pesticides and other toxic chemicals. J Expo Sci Environ Epidemiol. 2011;21:119-20.

27. Birnbaum LS, Cohen Hubal EA. Polybrominated diphenyl ethers: a case study for using biomonitoring data to address risk assessment questions. Environ Health Perspect. 2006;114:1770-5.

28. Cordner A, Mulcahy M, Brown P. Chemical regulation on fire: rapid policy advances on flame retardants. Environ Sci Technol. 2013;47:7067-76. Overview of how PBDE regulation has changed in response to scientific evidence and attention from advocacy groups and media.

29. Chen Y, Li J, Liu L, Zhao N. Polybrominated diphenyl ethers fate in China: a review with an emphasis on environmental contamination levels, human exposure and regulation. J Environ Manag. 2012;113:22-30.

30. Harrad S, Diamond ML. New directions: exposure to polybrominated diphenyl ethers (PBDEs) and polychlorinated biphenyls (PCBs): current and future scenarios. Atmos Environ. 2006;40: 1187-8.

31. Costa LG, Giordano G. Developmental neurotoxicity of polybrominated diphenyl ether (PBDE) flame retardants. Neurotoxicology. 2007;28:1047-67. Review of the toxicological evidence concerning the neurotoxicity of developmental PBDE exposure.

32. Costa LG, Giordano G. Is decabromodiphenyl ether (BDE209) a developmental neurotoxicant? Neurotoxicology. 2011;32: 9-24.

33. Williams AL, DeSesso JM. The potential of selected brominated flame retardants to affect neurological development. J Toxicol Environ Health B Crit Rev. 2010;13:411-48.

34. Eriksson P, Jakobsson E, Fredriksson A. Brominated flame retardants: a novel class of developmental neurotoxicants in our environment? Environ Health Perspect. 2001;109:903-8.

35. Eriksson P, Viberg H, Jakobsson E, Orn U, Fredriksson A. A brominated flame retardant, 2,2',4,4',5-pentabromodiphenyl ether: uptake, retention, and induction of neurobehavioral alterations in mice during a critical phase of neonatal brain development. Toxicol Sci. 2002;67:98-103.
36. Johansson N, Viberg H, Fredriksson A, Eriksson P. Neonatal exposure to deca-brominated diphenyl ether (PBDE 209) causes dose-response changes in spontaneous behaviour and cholinergic susceptibility in adult mice. Neurotoxicology. 2008;29:911-9.

37. Viberg H, Fredriksson A, Jakobsson E, Orn U, Eriksson P. Neurobehavioral derangements in adult mice receiving decabrominated diphenyl ether (PBDE 209) during a defined period of neonatal brain development. Toxicol Sci. 2003;76: $112-20$.

38. Viberg H, Johansson N, Fredriksson A, Eriksson J, Marsh G, et al. Neonatal exposure to higher brominated diphenyl ethers, hepta-, octa-, or nonabromodiphenyl ether, impairs spontaneous behavior and learning and memory functions of adult mice. Toxicol Sci. 2006;92:211-8.

39. Clancy B, Finlay BL, Darlington RB, Anand KJ. Extrapolating brain development from experimental species to humans. Neurotoxicology. 2007;28:931-7.

40. Viberg H, Fredriksson A, Eriksson P. Investigations of strain and/ or gender differences in developmental neurotoxic effects of polybrominated diphenyl ethers in mice. Toxicol Sci. 2004;81: 344-53.

41. Branchi I, Alleva E, Costa LG. Effects of perinatal exposure to a polybrominated diphenyl ether (PBDE 99) on mouse neurobehavioural development. Neurotoxicology. 2002;23:375-84.

42. Cheng J, Gu J, Ma J, Chen X, Zhang M, et al. Neurobehavioural effects, redox responses and tissue distribution in rat offspring developmental exposure to BDE-99. Chemosphere. 2009;75: 963-8.

43. Dufault C, Poles G, Driscoll LL. Brief postnatal PBDE exposure alters learning and the cholinergic modulation of attention in rats. Toxicol Sci. 2005;88:172-80.

44. He P, Wang A, Niu Q, Guo L, Xia T, et al. Toxic effect of PBDE47 on thyroid development, learning, and memory, and the interaction between PBDE-47 and PCB153 that enhances toxicity in rats. Toxicol Ind Health. 2011;27:279-88.

45. Gee JR, Moser VC. Acute postnatal exposure to brominated diphenylether 47 delays neuromotor ontogeny and alters motor activity in mice. Neurotoxicol Teratol. 2008;30:79-87.

46. Kuriyama SN, Talsness CE, Grote K, Chahoud I. Developmental exposure to low dose PBDE 99: effects on male fertility and neurobehavior in rat offspring. Environ Health Perspect. 2005;113: 149-54.

47. Rice DC, Reeve EA, Herlihy A, Zoeller RT, Thompson WD, et al. Developmental delays and locomotor activity in the C57BL6/J mouse following neonatal exposure to the fully-brominated PBDE, decabromodiphenyl ether. Neurotoxicol Teratol. 2007;29: 511-20.

48. Suvorov A, Girard S, Lachapelle S, Abdelouahab N, Sebire G, et al. Perinatal exposure to low-dose BDE-47, an emergent environmental contaminant, causes hyperactivity in rat offspring. Neonatology. 2009;95:203-9.

49. Ta TA, Koenig CM, Golub MS, Pessah IN, Qi L, et al. Bioaccumulation and behavioral effects of 2,2',4,4'-tetrabromodiphenyl ether (BDE-47) in perinatally exposed mice. Neurotoxicol Teratol. 2011;33:393-404.

50. Rice DC, Thompson WD, Reeve EA, Onos KD, Assadollahzadeh $\mathrm{M}$, et al. Behavioral changes in aging but not young mice after neonatal exposure to the polybrominated flame retardant decaBDE. Environ Health Perspect. 2009;117:1903-11.

51. Driscoll LL, Gibson AM, Hieb A. Chronic postnatal DE-71 exposure: effects on learning, attention and thyroxine levels. Neurotoxicol Teratol. 2009;31:76-84.

52.• Gascon M, Fort M, Martinez D, Carsin AE, Forns J, et al. Polybrominated diphenyl ethers (PBDEs) in breast milk and neuropsychological development in infants. Environ Health Perspect. 2012;120:1760-5. Longitudinal birth cohort study in Spain 
showing an association between increasing PBDE concentrations in colostrum and a worse infant mental development, particularly for $B D E-209$.

53.• Gascon M, Vrijheid M, Martinez D, Forns J, Grimalt JO, et al. Effects of pre and postnatal exposure to low levels of polybromodiphenyl ethers on neurodevelopment and thyroid hormone levels at 4 years of age. Environ Int. 2011;37:605-11. Longitudinal study showing associations between cord BDE concentrations, particularly BDE-47 and neurodevelopmental outcomes at 4 years; cross-sectional association between postnatal BDEs and outcomes measured at 4 years also examined.

54.• Roze E, Meijer L, Bakker A, Van Braeckel KN, Sauer PJ, et al. Prenatal exposure to organohalogens, including brominated flame retardants, influences motor, cognitive, and behavioral performance at school age. Environ Health Perspect. 2009;117:19538. First epidemiological study published examining correlations between cord BDE concentrations and a battery of tests of child behavior, cognition, and motor skills in Dutch children aged 5 6 years.

55.•• Eskenazi B, Chevrier J, Rauch SA, Kogut K, Harley KG, et al. In utero and childhood polybrominated diphenyl ether (PBDE) exposures and neurodevelopment in the CHAMACOS study. Environ Health Perspect. 2013;121:257-62. Longitudinal birth cohort study in California showing associations between prenatal maternal and childhood BDE concentrations and indices of child behavior, cognition, and motor skills at age 5 and 7.

56.• Herbstman JB, Sjodin A, Kurzon M, Lederman SA, Jones RS, et al. Prenatal exposure to PBDEs and neurodevelopment. Environ Health Perspect. 2010;118:712-9. Longitudinal birth cohort study in New York City showing associations between cord blood BDE concentrations and child mental developmental index and IQ at ages 1-7 years.

57.• Hoffman K, Adgent M, Goldman BD, Sjodin A, Daniels JL. Lactational exposure to polybrominated diphenyl ethers and its relation to social and emotional development among toddlers. Environ Health Perspect. 2012;120:1438-42. Longitudinal study in North Carolina meauring PBDEs in breast milk and child behavior at age 1-3 years.

$58 . \bullet$ Chao HR, Tsou TC, Huang HL, Chang-Chien GP. Levels of breast milk PBDEs from southern Taiwan and their potential impact on neurodevelopment. Pediatr Res. 2011;70:596-600. Longitudinal birth cohort study in Taiwan measuring PBDE concentrations in breast milk and neurodevelopment at age 8-12 months.

59.• Shy CG, Huang HL, Chang-Chien GP, Chao HR, Tsou TC. Neurodevelopment of infants with prenatal exposure to polybrominated diphenyl ethers. Bull Environ Contam Toxicol. 2011;87:643-8. Longitudinal birth cohort study in Taiwan measuring PBDE concentrations in a small number of cord blood samples and neurodevelopment at age 8-12 months.

60. Frederiksen M, Thomsen C, Froshaug M, Vorkamp K, Thomsen $\mathrm{M}$, et al. Polybrominated diphenyl ethers in paired samples of maternal and umbilical cord blood plasma and associations with house dust in a Danish cohort. Int J Hyg Environ Health. 2010;213:233-42.

61. Briggs-Gowan MJ, Carter AS, Bosson-Heenan J, Guyer AE, Horwitz SM. Are infant-toddler social-emotional and behavioral problems transient? J Am Acad Child Adolesc Psychiatry. 2006;45:849-58.

62. Dickersin K. The existence of publication bias and risk factors for its occurrence. JAMA. 1990;263:1385-9.

63. Park JS, Holden A, Chu V, Kim M, Rhee A, et al. Timetrends and congener profiles of PBDEs and PCBs in California peregrine falcons (Falco peregrinus). Environ Sci Technol. 2009;43:8744-51.

64. Darnerud PO, Aune M, Atuma S, Becker W, Bjerselius R, et al. Time trend of polybrominated diphenyl ether (PBDE) levels in breast milk from Uppsala, Sweden, 1996-2001. Organohalogen Compounds. 2002;58:233-236.

65. Sjodin A, Jones RS, Caudill SP, Wong LY, Turner WE, et al. Polybrominated diphenyl ethers, polychlorinated biphenyls, and persistent pesticides in serum from the national health and nutrition examination survey: 2003-2008. Environ Sci Technol. 2014;48:753-60. Comparison of BDE concentrations measured in serum samples from NHANES participants in survey years 2003/04, 2005/06, and 2007/08.

66. Jones R, Edenfield E, Anderson S, Zhang Y, Sjodin A. Semiautomated extraction and cleanup method for measuring persistent organic polutants in human serum. Organohalogen Compd. 2012;4:97-8

67. Sjodin A, Jones RS, Lapeza CR, Focant JF, McGahee 3rd EE, et al. Semiautomated high-throughput extraction and cleanup method for the measurement of polybrominated diphenyl ethers, polybrominated biphenyls, and polychlorinated biphenyls in human serum. Anal Chem. 2004;76:1921-7.

68. McCauley SR, Wilde EA, Anderson VA, Bedell G, Beers SR, et al. Recommendations for the use of common outcome measures in pediatric traumatic brain injury research. J Neurotrauma. 2012;29:678-705.

69. Howdeshell KL. A model of the development of the brain as a construct of the thyroid system. Environ Health Perspect. 2002;110 Suppl 3:337-48.

70. DeLong GR, Stanbury JB, Fierro-Benitez R. Neurological signs in congenital iodine-deficiency disorder (endemic cretinism). Dev Med Child Neurol. 1985;27:317-24.

71. Webb SJ, Monk CS, Nelson CA. Mechanisms of postnatal neurobiological development: implications for human development. Dev Neuropsychol. 2001;19:147-71.

72. Tau GZ, Peterson BS. Normal development of brain circuits. Neuropsychopharmacology. 2010;35:147-68.

73. Porterfield SP. Vulnerability of the developing brain to thyroid abnormalities: environmental insults to the thyroid system. Environ Health Perspect. 1994;102 Suppl 2:125-30.

74. Horn S, Heuer H. Thyroid hormone action during brain development: more questions than answers. Mol Cell Endocrinol. 2010;315:19-26.

75. Hamers T, Kamstra JH, Sonneveld E, Murk AJ, Kester $\mathrm{MH}$, et al. In vitro profiling of the endocrine-disrupting potency of brominated flame retardants. Toxicol Sci. 2006;92:15773.

76. Meerts IA, van Zanden JJ, Luijks EA, van Leeuwen-Bol I, Marsh $\mathrm{G}$, et al. Potent competitive interactions of some brominated flame retardants and related compounds with human transthyretin in vitro. Toxicol Sci. 2000;56:95-104.

77. Talsness CE, Kuriyama SN, Sterner-Kock A, Schnitker P, Grande $\mathrm{SW}$, et al. In utero and lactational exposures to low doses of polybrominated diphenyl ether- 47 alter the reproductive system and thyroid gland of female rat offspring. Environ Health Perspect. 2008;116:308-14.

78. Kodavanti PR, Coburn CG, Moser VC, MacPhail RC, Fenton SE, et al. Developmental exposure to a commercial PBDE mixture, DE-71: neurobehavioral, hormonal, and reproductive effects. Toxicol Sci. 2010;116:297-312.

79. Kuriyama SN, Wanner A, Fidalgo-Neto AA, Talsness CE, Koerner W, et al. Developmental exposure to low-dose PBDE99: tissue distribution and thyroid hormone levels. Toxicology. 2007:242:80-90.

80. Lee E, Kim TH, Choi JS, Nabanata P, Kim NY, et al. Evaluation of liver and thyroid toxicity in Sprague-Dawley rats after exposure to polybrominated diphenyl ether BDE-209. J Toxicol Sci. 2010;35: 535-45.

81. Tseng LH, Li MH, Tsai SS, Lee CW, Pan MH, et al. Developmental exposure to decabromodiphenyl ether (PBDE 209): effects on 
thyroid hormone and hepatic enzyme activity in male mouse offspring. Chemosphere. 2008;70:640-7.

82. Zhou T, Ross DG, DeVito MJ, Crofton KM. Effects of short-term in vivo exposure to polybrominated diphenyl ethers on thyroid hormones and hepatic enzyme activities in weanling rats. Toxicol Sci. 2001;61:76-82.

83. Zhou T, Taylor MM, DeVito MJ, Crofton KM. Developmental exposure to brominated diphenyl ethers results in thyroid hormone disruption. Toxicol Sci. 2002;66:105-16.

84. Zhang S, Bursian SJ, Martin PA, Chan HM, Tomy G, et al. Reproductive and developmental toxicity of a pentabrominated diphenyl ether mixture, DE-71, to ranch mink (Mustela vison) and hazard assessment for wild mink in the Great Lakes region. Toxicol Sci. 2009;10:107-16.

85. Abdelouahab N. PBDE at early pregnancy and thyroid hormones: first results from GESTE birth cohort study. 12th Workshop on Brominated and other Flame Retardants. Boston, MA; 2011.

86. Eggesbo M, Thomsen C, Jorgensen JV, Becher G, Odland JO, et al. Associations between brominated flame retardants in human milk and thyroid-stimulating hormone (TSH) in neonates. Environ Res. 2011;111:737-43.

87. Kim TH, Lee YJ, Lee E, Patra N, Lee J, et al. Exposure assessment of polybrominated diphenyl ethers (PBDE) in umbilical cord blood of Korean infants. J Toxicol Environ Health A. 2009;72: 1318-26.

88. Herbstman JB, Sjodin A, Apelberg BJ, Witter FR, Halden RU, et al. Birth delivery mode modifies the associations between prenatal polychlorinated biphenyl (PCB) and polybrominated diphenyl ether (PBDE) and neonatal thyroid hormone levels. Environ Health Perspect. 2008;116:1376-82.

89. Lin SM, Chen FA, Huang YF, Hsing LL, Chen LL, et al. Negative associations between PBDE levels and thyroid hormones in cord blood. Int J Hyg Environ Health. 2011;214:115-20.

90. Fowles JR, Fairbrother A, Baecher-Steppan L, Kerkvliet NI. Immunologic and endocrine effects of the flame-retardant pentabromodiphenyl ether (DE-71) in C57BL/6J mice. Toxicology. 1994;86:49-61.

91. Hallgren S, Darnerud PO. Polybrominated diphenyl ethers (PBDEs), polychlorinated biphenyls (PCBs) and chlorinated paraffins (CPs) in rats-testing interactions and mechanisms for thyroid hormone effects. Toxicology. 2002;177:227-43.

92. Hallgren S, Sinjari T, Hakansson H, Darnerud PO. Effects of polybrominated diphenyl ethers (PBDEs) and polychlorinated biphenyls (PCBs) on thyroid hormone and vitamin A levels in rats and mice. Arch Toxicol. 2001;75:200-8.

93. Dallaire R, Dewailly E, Pereg D, Dery S, Ayotte P. Thyroid function and plasma concentrations of polyhalogenated compounds in Inuit adults. Environ Health Perspect. 2009;117:1380-6.
94. Meeker JD, Johnson PI, Camann D, Hauser R. Polybrominated diphenyl ether (PBDE) concentrations in house dust are related to hormone levels in men. Sci Total Environ. 2009;407:3425-9.

95. Turyk ME, Persky VW, Imm P, Knobeloch L, Chatterton R, et al. Hormone disruption by PBDEs in adult male sport fish consumers. Environ Health Perspect. 2008;116:1635-41.

96. Bloom M, Spliethoff H, Vena J, Shaver S, Addink R, et al. Environmental exposure to PBDEs and thyroid function among New York anglers. Environ Toxicol Pharmacol. 2008;25:386-92.

97. Julander A, Karlsson M, Hagstrom K, Ohlson CG, Engwall M, et al. Polybrominated diphenyl ethers: plasma levels and thyroid status of workers at an electronic recycling facility. Int Arch Occup Environ Health. 2005;78:584-92.

98. Fisher DA, Dussault JH, Sack J, Chopra IJ. Ontogenesis of hypothalamic-pituitary-thyroid function and metabolism in man, sheep, and rat. Recent Prog Horm Res. 1976;33:59-116.

99. Abdelouahab N, Suvorov A, Pasquier JC, Langlois MF, Praud JP, et al. Thyroid disruption by low-dose BDE-47 in prenatally exposed lambs. Neonatology. 2009;96:120-4.

100. Chevrier J, Harley KG, Bradman A, Gharbi M, Sjodin A, et al. Polybrominated diphenyl ether (PBDE) flame retardants and thyroid hormone during pregnancy. Environ Health Perspect. 2010;118:1444-9.

101. Stapleton HM, Eagle S, Anthopolos R, Wolkin A, Miranda ML. Associations between polybrominated diphenyl ether (PBDE) flame retardants, phenolic metabolites, and thyroid hormones during pregnancy. Environ Health Perspect. 2011;119:1454-9.

102. Costa LG, Giordano G, Tagliaferri S, Caglieri A, Mutti A. Polybrominated diphenyl ether (PBDE) flame retardants: environmental contamination, human body burden and potential adverse health effects. Acta Biomed. 2008;79:172-83.

103. Huang YM, Chen LG, Xu ZC, Peng XC, Wen LJ, et al. Preliminary study of PBDE levels in house dust and human exposure to PBDEs via dust ingestion. Huan Jing Ke Xue. 2010;31:168-72.

104. Tagliaferri S, Caglieri A, Goldoni M, Pinelli S, Alinovi R, et al. Low concentrations of the brominated flame retardants BDE-47 and BDE-99 induce synergistic oxidative stress-mediated neurotoxicity in human neuroblastoma cells. Toxicol In Vitro. 2010;24: 116-22.

105. Dingemans MM, van den Berg M, Westerink RH. Neurotoxicity of brominated flame retardants: (in)direct effects of parent and hydroxylated polybrominated diphenyl ethers on the (developing) nervous system. Environ Health Perspect. 2011;119:900-7.

106. Foster TC. Calcium homeostasis and modulation of synaptic plasticity in the aged brain. Aging Cell. 2007;6:319-25.

107. Schreiber T, Gassmann K, Gotz C, Hubenthal U, Moors M, et al. Polybrominated diphenyl ethers induce developmental neurotoxicity in a human in vitro model: evidence for endocrine disruption. Environ Health Perspect. 2010;118:572-8. 